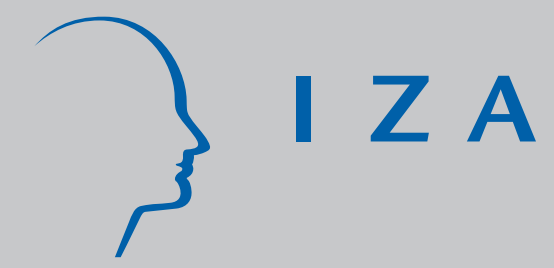

IZA DP No. 110

A Theory of Social Forces and Immigrant Second Language Acquisition

Don DeVoretz

Christiane Werner

February 2000 


\title{
A Theory of Social Forces and Immigrant Second Language Acquisition
}

\author{
Don DeVoretz \\ RIIM, Simon Fraser University, Canada and IZA, Bonn \\ Christiane Werner \\ RIIM, Simon Fraser University, Canada
}

\author{
Discussion Paper No. 110 \\ February 2000
}

\author{
IZA \\ P.O. Box 7240 \\ D-53072 Bonn \\ Germany \\ Tel.: +49-228-3894-0 \\ Fax: +49-228-3894-210 \\ Email: iza@iza.org
}

This Discussion Paper is issued within the framework of IZA's research area Mobility and Flexibility of Labor Markets. Any opinions expressed here are those of the author(s) and not those of the institute. Research disseminated by IZA may include views on policy, but the institute itself takes no institutional policy positions.

The Institute for the Study of Labor (IZA) in Bonn is a local and virtual international research center and a place of communication between science, politics and business. IZA is an independent, nonprofit limited liability company (Gesellschaft mit beschränkter Haftung) supported by the Deutsche Post AG. The center is associated with the University of Bonn and offers a stimulating research environment through its research networks, research support, and visitors and doctoral programs. IZA engages in (i) original and internationally competitive research in all fields of labor economics, (ii) development of policy concepts, and (iii) dissemination of research results and concepts to the interested public. The current research program deals with (1) mobility and flexibility of labor markets, (2) internationalization of labor markets and European integration, (3) the welfare state and labor markets, (4) labor markets in transition, (5) the future of work, (6) project evaluation and (7) general labor economics.

IZA Discussion Papers often represent preliminary work and are circulated to encourage discussion. Citation of such a paper should account for its provisional character. 


\title{
ABSTRACT \\ A Theory of Social Forces and Immigrant Second Language Acquisition
}

The preponderance of minimal second language acquisition by immigrants worldwide is striking. This paper proposes a theoretical model, which analyzes the underlying forces that contribute to this outcome of minimal secondary language acquisition by immigrants in such diverse immigrant-receiving countries as Canada, Germany, Israel and the United States. It is argued that the weak incentive structures for second language acquisition for an immigrant appear in four analytically separate spheres including the labour market, political, social, and education spheres. Furthermore, two integration regimes are imposed in these spheres - no government interference, or government-mandated minimum language acquisition after arrival. In all cases and in all spheres, it is argued that, for the majority of immigrants, the weakest level of second language acquisition - minimum oral and minimum written - is the optimal outcome given their incentive structure. In addition, the labour market is the primary determinant of this outcome. Finally, several policy measures to increase the incentives for further second language acquisition are explored.

JEL Classification: J24, J61

Keywords: Immigration, ethnic Germans, Canada, language acquisition, labour market, integration, assimilation

\author{
Don DeVoretz \\ RIIM \\ Simon Fraser University \\ Burnaby, BC, V5A 156 \\ Canada \\ Tel.: +1 $604291-4575$ \\ Fax: $+1604291-5336$ \\ E-mail: devoretz@sfu.ca
}

\footnotetext{
"This paper is dedicated to Dr. H. Grubel, and was originally presented at his Festschrift, October, 1999. The critical comments of H. Hinte, D. Coulombe and C. Iturralde are noted with appreciation. The author also thanks Sydney Preston for her copyediting services. Generous financial support was provided by IZA to the authors.
} 


\section{Introduction}

Israel, Germany, Australia and Canada confront their recent immigrant arrivals with a wide array of mandated linguistic environments and legislated standards for second language ${ }^{1}$ acquisition. At the one extreme is Canada, which requires no competency in either of its official languages for admission, and after admission little second language acquisition is required to obtain Canadian citizenship. ${ }^{2}$ In particular, Canada admits approximately 200,000 immigrants yearly with a minority of them speaking one of Canada's two official languages. In addition, the co-existence of English and French as official languages in the context of legislated multiculturalism presents recent Canadian immigrants with at least four linguistic options: English, French, facility in both languages or maintenance of their home language in English-speaking Canada. In Quebec, with a near independent immigrant admission system, non-French options are limited for the recent immigrant. ${ }^{3}$ This multi-layered linguistic choice facing immigrants leads to a variety of less than satisfactory outcomes in terms of second language acquisition.

In contrast, Germany and Israel both have strong legislated mandates to compel their recent arrivals to acquire their mainstream languages. In particular, for Germany, both the admission of Ausseidler and the acquisition of citizenship by Auslander require a demonstration of German language proficiency. Israel has, of course, made the acquisition of Hebrew a cornerstone of its immigrant integration and national goals. The post-1989 arrival of several hundred thousand Russian-speaking Jews challenged the traditional role of Hebrew language acquisition as an integration tool. Political parties have called for the maintenance of the Russian language in Israel along with associated Russian language institutions such as the theatre and television. In sum, the main immigrant-receiving countries provide a variety of second language acquisition regimes: laissez-faire for Canada, cultural/religious compulsion for Israel and a

\footnotetext{
1 "[The term 'second language' is used throughout this article to refer to any language other than the native language. Thus it is synonymous with 'foreign language'.]” (Gardner and MacIntyre 1992, 211)

${ }^{2}$ See Werner, Hinte and DeVoretz (2000) for a complete exposition on Canada's linguistic policy.

${ }^{3}$ In Quebec, under the Chartre de la langue française, most immigrants enter the French school system and receive instruction in English as a second language. English-educated parents have the right to enrol their children in English schools where French is the second language.
} 
cultural/political imperative for Germany, which yields a paradox. Regardless of the second language acquisition regime, recent immigrant second language acquisition has been weak and declining. It is the goal of this paper to propose a theoretical model to rationalize this observation.

In this paper, we develop an optimum language acquisition model for four activity spheres for immigrants to isolate the largely economic forces that have led to mediocre second immigrant language acquisition under a variety of policy regimes. These analyzed spheres include the labour market, politics, education, and the social-marriage network. We evaluate the immigrant linguistic integration experience in each sphere to provide insights into the underlying incentive system for language acquisition and to predict, in the absence of government intervention, what level of foreign-born language acquisition will voluntarily result in each activity sphere. Next, we introduce stylized second language policies in these various spheres to represent mandated language policies of both various governments and their quasi-legal bodies. Under these regimes, the model predicts the degree of second language acquisition. We strongly conclude that the optimal choice of second language acquisition by an immigrant under most policy regimes is minimum oral and written second language acquisition. Moreover, in the absence of economic incentives, government compulsion to acquire a second language does not induce second language acquisition but increases the incentives for return migration or leads to cultural and labour segmentation.

\section{Spheres of Language Acquisition}

The central point to be drawn from the following analysis is that no one-degree of second language acquisition may be optimal for an immigrant in any one social sphere. In short, within each sphere, an incentive system will emerge that will encourage the individual to acquire (in the absence of a subsidy or compulsion) a mix of language skills depending on his individual characteristics. What level of the second language is acquired, and what is the dominant sphere of influence, are two central questions of interest to policy makers. We now review each social sphere and the probable optimal second language acquisition levels ad seriatim. 
A. Labour Market

Figure 1: Second Language Acquisition in the Labour Market

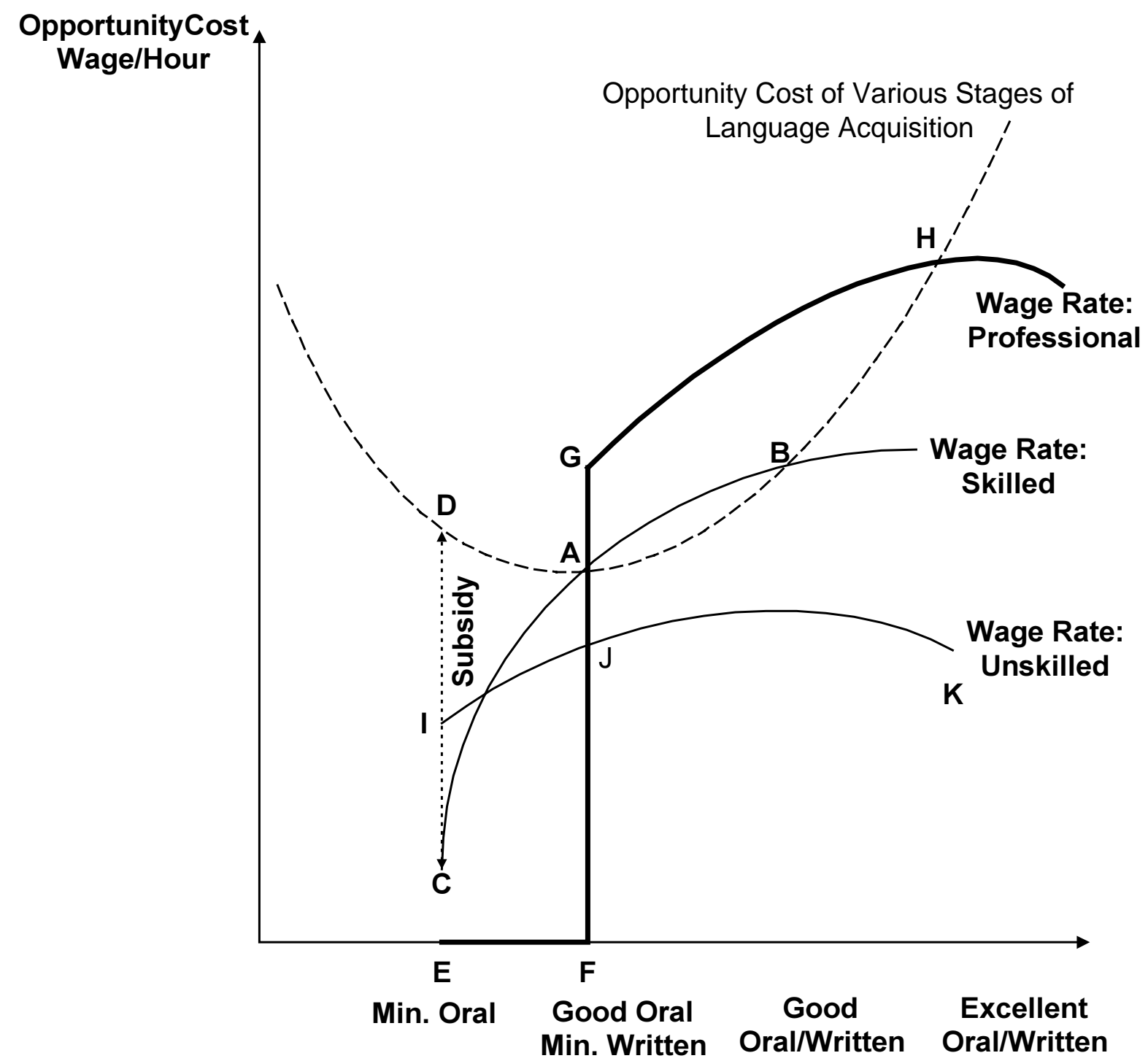

Figure 1 presents a stylized view of language acquisition in the labour market that will help rationalize weak second language acquisition in the face of seemingly strong economic incentives. For example, in the labour market in Figure 1, it is assumed that everyone arrives with at least a minimum of oral language skills in the official language. The cost of language acquisition is DABH and is $\mathrm{U}$-shaped. This shape reflects the fact that, at least for oral language acquisition, the learning curve is logarithmic and language learning initially increases at an 
increasing rate. Hence, the cost in terms of time spent learning a given amount of language facility at first falls, then reaches a minimum before rising again. This cost can be monetized for an employed worker by multiplying the unit learning time by his/her wage rate, plus tuition and the disutility associated with learning.

One central inference from Figure 1 is that the acquisition of various degrees of second language skills is a function of the immigrant's occupation and/or skill level upon arrival and the resulting returns earned in the labour market from any further second language acquisition. We cite some examples to illustrate this proposition. Unskilled workers, perhaps females, will never move past minimum oral skills since the cost of language acquisition (ED) always exceeds the wage rate (IE) in these unskilled occupations regardless of their future potential language ability. However, both the skilled and professionally trained immigrants, subject to the availability of sufficient financing, will improve their language skills since they have an economic incentive to reach, respectively, equilibrium $\mathrm{B}$ for skilled workers (good oral/ written) or equilibrium $\mathrm{H}$ for professionals (excellent oral and written skills). In the absence of a subsidy, those immigrants who arrive with minimum oral skills will never obtain language skills beyond the minimum oral level.

In the above economic world of Figure 1, self-financing is uncertain. Given either a subsidy in the form of a family loan (if married to an unskilled earning E I) or a government loan, however, will allow the skilled person to acquire second language skills and to reach the crossover point of A with good oral skills. After that point, the skilled worker will self-finance further education until equilibrium point $B$ where further second language acquisition ceases since the wage rate equals the marginal cost of language acquisition. If no subsidy is forthcoming from the family or government, and in the absence of an efficient capital market, the default occupational position for a skilled immigrant worker with only minimal oral language abilities will be an unskilled job. This outcome is clear since unskilled work, even for a skilled immigrant, yields a higher initial wage with minimal oral skills than does the skilled occupation with only minimal oral skills. Hence, under the no subsidy condition, no language investment is made and 
the skilled person remains at language equilibrium $\mathrm{E}$ with minimal oral language capabilities in an unskilled occupation.

Professionals have a different path of language acquisition in the form of a step function. In order to qualify for membership in their profession, good oral and good written skills are required given the existence of a formal qualifying examination. ${ }^{4}$ Once they obtain the language proficiency level to pass a formal written examination, professionals will self-finance until $\mathrm{H}$, gaining excellent oral and written language skills. If, however, professionals do not obtain at least good oral and minimum written skills, they will either emigrate or enter the unskilled labour market. In sum, in the labour market, individuals will acquire different language capabilities given their skill endowment, initial language abilities and financing schemes. Nevertheless, the most common equilibrium second language position is minimal oral and written.

What of other activity spheres? For example, the political sphere. Will this sphere of activity produce a similar level of language acquisition such that the immigrant achieves an identical language capability in both the economic and political spheres? Moreover, if an individual voluntarily arrives at two different levels of language acquisition in the political and labour market sphere, which sphere ultimately determines the degree of language acquisition? We address these issues in the next two sections.

\footnotetext{
${ }^{4}$ See Werner, Hinte and DeVoretz (2000) for an outline of the stringent official language requirements in Canada for professional certification across a wide spectrum of professions.
} 
Figure 2: Second Language Acquisition in the Political Sphere

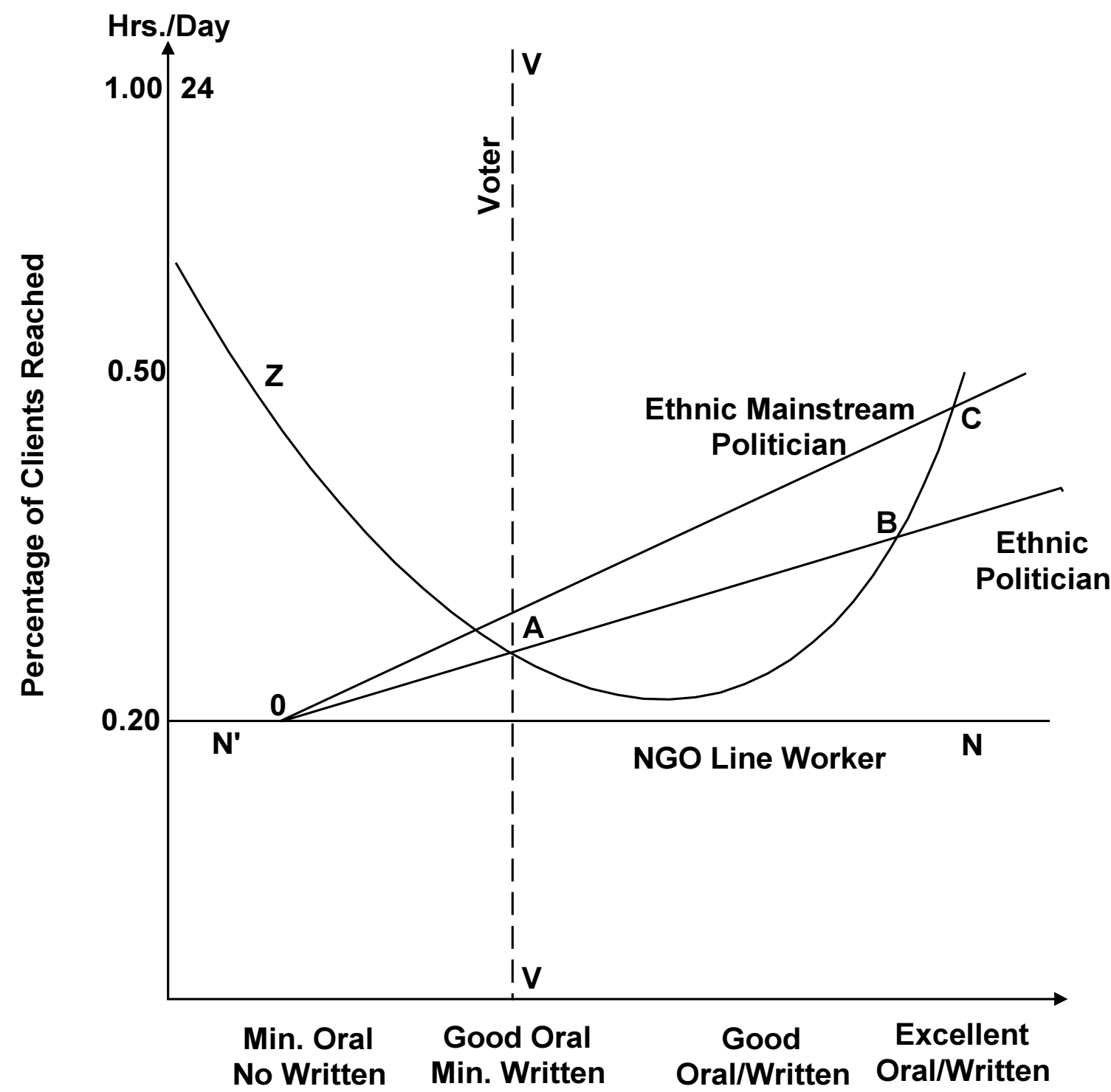

B. Political Sphere

In the political sphere, an immigrant can choose different political activity levels, which require varying levels of language acquisition. These activities correspond to different political occupations: a voter, a non-governmental organization (NGO) advocate, or an ethnic or mainstream elected official. Figure 2 maps the percentage of the electorate that can be reached with various associated language skills. It is argued here that each chosen level of political 
activity — voter, candidate, an elected official — requires some minimum constituency with which to communicate. The greater the size of the required constituency the greater the percentage of mainstream speakers that must be reached, and hence the greater the need for more facile mainstream language capabilities by the candidate or NGO activist. For example, in Figure 2 we assert that 20 percent of this riding speaks only an immigrant heritage language. The cost function for language acquisition is again U-shaped. ${ }^{5}$ Now the choice problem is straightforward, to wit, the individual chooses his/her type of political activity: a simple voter, ethnic NGO worker, ethnic politician or mainstream politician, based on a calculus of costs and benefits. Each activity implies a different minimum level of language acquisition in order to be successful. For example, an immigrant may choose only to participate by voting and thus must obtain the prerequisite citizenship. Citizenship in turn requires some implied level of mainstream language skill, such as no oral and minimum written skills for Canadian citizens. This language requirement for citizenship is depicted by $\mathrm{V}-\mathrm{V}$ or the legal requirement for citizenship (e.g. good oral and minimum written skills). On the other hand, if a recent immigrant chooses not to vote, but to work for an ethnic lobby group (NGO or non-governmental organization), this activity could, conceivably, be conducted without any knowledge of the mainstream language. Thus the line $\mathrm{N}^{\prime}-\mathrm{N}$ for the NGO worker or a horizontal line, which represents the return from language in terms of reaching the NGO constituency with various levels of language acquisition. The height of the intercept of this horizontal line represents the percentage size of this constituency in the NGO group. Since any mainstream language acquisition costs time, and thus reduces contact with constituents, a corner solution at $\mathrm{N}^{\prime}$ of no oral or written language skills is the equilibrium level of language acquisition for an NGO worker.

What of a political candidate and his associated optimum level of mainstream language skills? A potential ethnic candidate who seeks election in an uni-ethnic riding with minimum oral and no written language skills will acquire mainstream language skills to converse with an everwider constituency if and only if additional mainstream voters are required to insure election. For

\footnotetext{
${ }^{5}$ Cost is measured in two forms, lost time in the labour market as well as time spent with constituents and tuition.
} 
example, if there are three parties and the ethnic politician can only contact 20 percent of the voters in his heritage language, he must reach a wider audience (34 percent) to gain the necessary votes and insure victory. Given the cost of language acquisition, the maximum language skills obtained by this ethnic politician are good oral/good written or B. If fewer number of voters are needed (say five parties are in the riding), then the equilibrium level of language acquisition will be at A with good oral mainstream language skills but minimum written skills. Finally, if an ethnic politician has national ambitions, but initially limited mainstream language skills, then the equilibrium language skills must ultimately be excellent in both written and oral if more than $50 \%$ of the riding is to be reached. Thus, given the cost of language acquisition, $\mathrm{C}$ is the equilibrium position of language attainment with excellent language skills. ${ }^{6}$

\footnotetext{
${ }^{6} \mathrm{O}-\mathrm{D}-\mathrm{C}$ lies everywhere above $\mathrm{OAB}$ since it is asserted that via self-selection an ethnic mainstream
} politician has superior language skills. 
C. Social Sphere

Figure 3: Second Language Acquisition and Social Matching

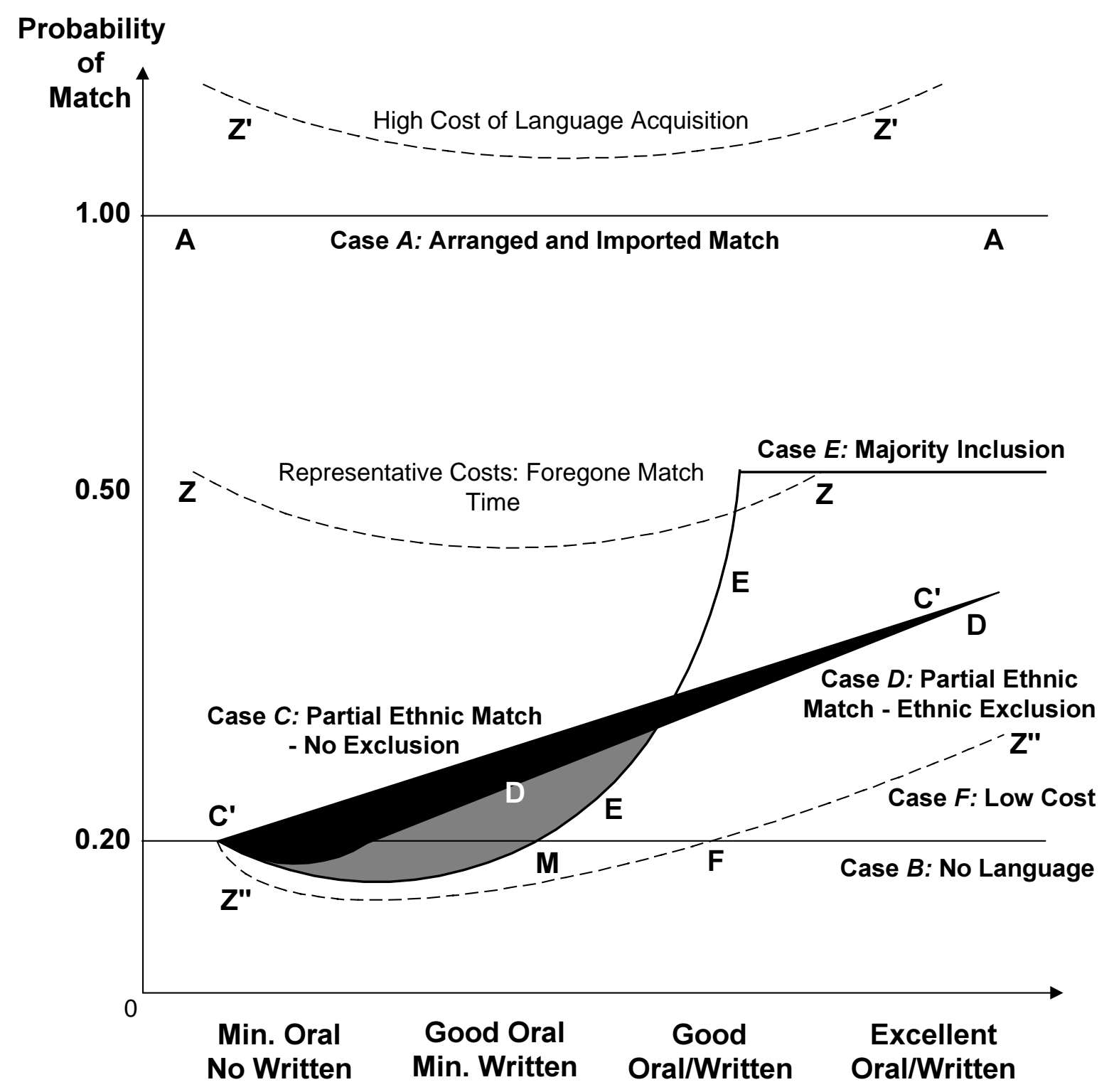

Immigrants also act in a social sphere in which paired matches are the essential goal. These matches can lead to friendship, marriage, procreation or recreation. The probability of a suitable match depends on a constellation of characteristics, which are defined by individual tastes. Second language acquisition may improve the probability of making a suitable match. In Figure 3, it is asserted that the goal of a newly arrived immigrant is to have a long-term match, in 
this case marriage. Ethnicity and language facility can alter the probability of a successful match. In case $A$, an arranged marriage takes place (probability $=1$ ) where a fee is paid for a certain ethnic match. The potential spouse is imported for the match when the cost of language acquisition ( $Z^{\prime}-$ Z') for this immigrant lies everywhere above the cost of an arranged match at A-A. ${ }^{7}$ Again, language acquisition cost is measured as the time required to learn a given amount of language, which reduces the probability (at first) of a match. Thus, at min oral and no written language skills the probability of a match is certain (i.e. 100 percent) since an arranged marriage insures this outcome. Obviously, no further second language acquisition will occur since in this case language acquisition is very costly and does not improve the prospect of a match, which is certain to begin with under an arranged situation. ${ }^{8}$

For those immigrants who face a high cost curve, $Z^{\prime}-Z^{\prime}$, and who cannot afford the contracted market we assert in case $\mathrm{B}$, the maximum probability of the match is .2 since in this example, 40 per cent of the community speaks the immigrant's language. Given the high cost of language acquisition ( $\left.Z^{\prime}-Z^{\prime}\right)$ and an inability to finance a contracted marriage, the ethnic immigrant chooses no language acquisition (B-B) and a one-in-five probability of a successful match.

What if the immigrant wants to improve his or her chances for a successful match in the destination country? Then he/she must learn the dominant language and move out into the nonethnic population. Three further cases - C, D and E - now appear. In two of the three cases (D and E), acquiring greater second language skills and moving from the condition of min oral and no written second language ability to good oral and minimum written second language skills at first reduces (C'EFG or C'DD) the probability of a match. Why? Because it can be argued that some members of the ethnic community will begin to exclude ethnic learners of the dominant language. In the second stage, the acquisition of greater second language skills increases the probability of a match in the dominant population more than the loss of a match in the ethnic

\footnotetext{
${ }^{7}$ In case A, the U-shaped cost curve for language is above AAA, which asserts that in this case this individual is older and lacks language facility.

${ }^{8}$ In particular, some immigrant-receiving countries have legislation, which facilitates this outcome given spousal sponsorship provisions with no language or other economic assessment criteria.
} 
community owing to ethnic exclusion. Thus, the relevant probability curve for a match rises with greater second language acquisition. Only in a tolerant society, where there exists no exclusion (case C) by the ethnic group of ethnic learners of a second language, will the probability line for a match increase throughout the period of second language acquisition or $C^{\prime}-C^{\prime}-C^{\prime}$. Case $E$ is the most robust in that it combines ethnic exclusion, and majority inclusion. In this complex but realistic society, the probability of match initially declines $\left(\mathrm{C}^{\prime} \mathrm{M}\right)$ with some mainstream language acquisition as the ethnic community partially shuns the ethnic language learner. Then, as more language is acquired, the probability of a match rises (ME) to an arbitrarily defined (in this paper) maximum of one-half (.5) in an inclusive majority society with no residual exclusion by the ethnic population. $^{9}$

What generalization(s) emerges from this analysis of social sphere? In most of the cases illustrated in Figure 3, the optimal second language acquisition strategy for a social match is to have minimum oral and no written equilibrium skills if the costs are either high ( $\left.Z^{\prime} Z^{\prime}\right)$ or medium (ZZ). In a more optimistic world where language acquisition is more efficient or less costly (language acquired during leisure hours), or if language classes actually increase the probability of match by meeting similar prospects in the language class, then the marginal cost drops to $\mathrm{ZZ}$ (i.e. below .20). Now the equilibrium level of second language acquisition growing to good oral and good written skills in the second language is realized, as in case F.

\section{Educational sphere}

The educational sector often mandates second language acquisition by immigrant children as a prerequisite for further education. Thus, second language acquisition often occurs in an immersion environment and initially dominates the immigrant's school experience. This type of second language acquisition is costless in the sense we earlier defined since their exists no tuition costs or foregone opportunities in the labour market. ${ }^{10}$ Even in the absence of explicit costs and in the presence of a mandated and comprehensive immersion program, a common set of cross-

\footnotetext{
${ }^{9}$ If the match were a heterosexual union, $(.5)$ is the maximum probability for the population as a whole.
} 
country outcomes occurs. Namely, many students obtain only mediocre second language skills, which subsequently leads to substantial foreign-born attrition rates from school. The economic implications of this situation are obvious but what is less obvious is the impact of potentially weak economic outcomes on this low level of formal second language acquisition by school-age immigrants. We turn to a formal analysis below to understand this relationship.

Figure 4: Second Language Acquisition in the Educational Sector

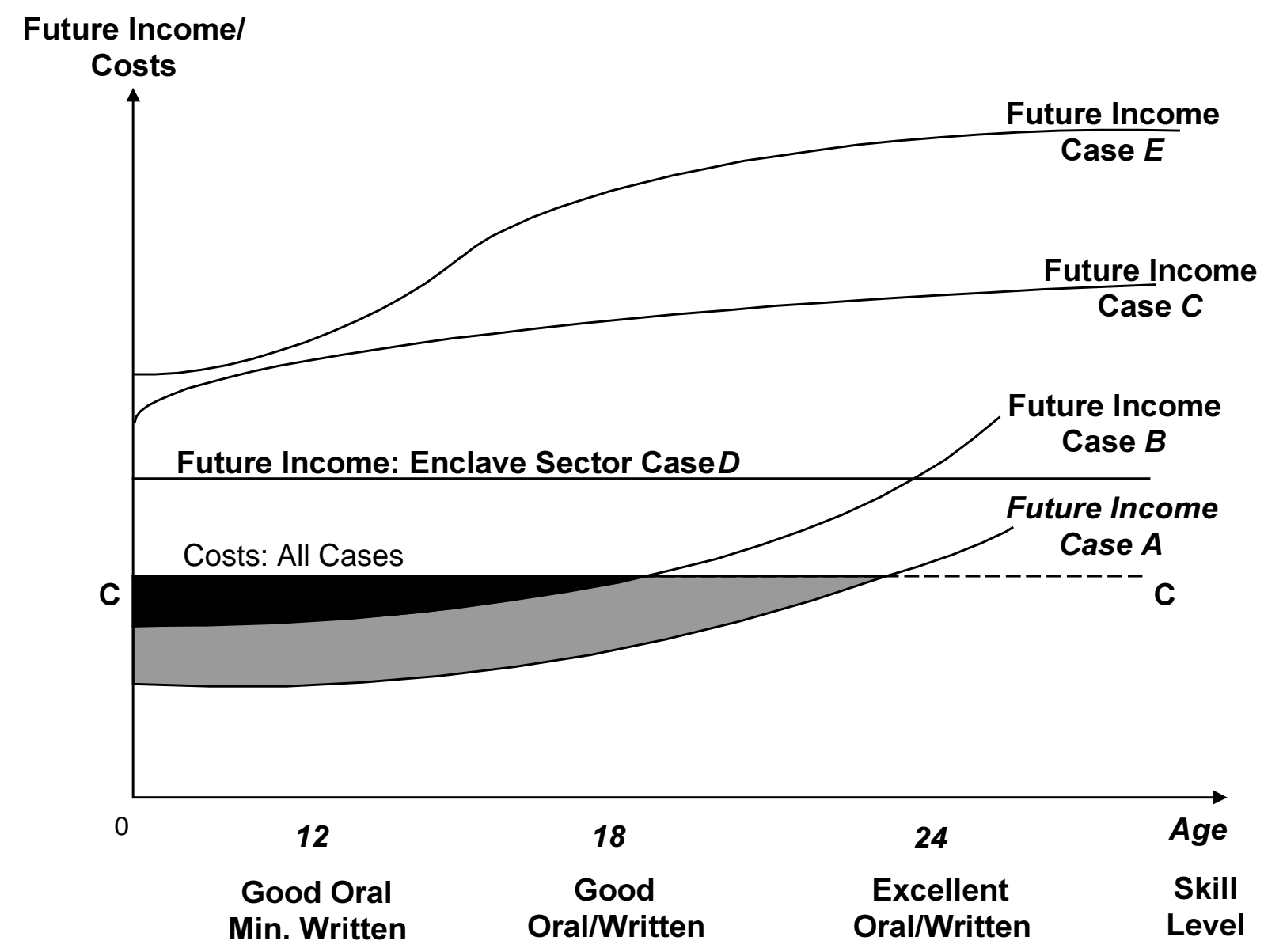

Figure 4 depicts the typical range of second language acquisition from minimum oral/written to excellent linguistic skills. In this sphere, the economic gains from second language

\footnotetext{
${ }^{10}$ Most but not all students would not be eligible to join the labour market and hence foregone income would be small.
} 
acquisition are contingent upon further completion of formal education in order to gain a labour market skill. It is asserted that any immigrant student would aspire to excellent oral and written second language skills if the ultimate human capital acquisition yielded a competitive payoff in the labour market (i.e. professional occupation in Figure 1). Perceived or real employment barriers or the need for immediate labour market entry at the unskilled level are powerful negative economic forces that reduce the incentive of second language acquisition and subsequently increase the attrition rate from high school of immigrant students. We provide three prototypical cases that depict the conditions leading to three states of language acquisition in the formal education sector. Case A yields an equilibrium with good oral and minimum written second language skill acquisition in school, while cases B and C illustrate the incentive structure for successively greater amounts of second language acquisition under more favorable future labour market outcomes.

Case A depicts the frequent situation in which immigrant children leave school with good oral and minimum written skills at the mandated minimum age prior to completion of secondary school. The line $\mathrm{C}-\mathrm{C}$ depicts the constant discounted costs of attending language classes after the leaving age (16). This constant cost $\mathrm{OC}$ of second language acquisition for each year in school is a product of the minimum wage plus some valuation attributed to loss of leisure while the immigrant student acquires additional education and second language skills. In case A, the prospective student faces a meager earning stream in which the additional discounted value of income obtained by acquiring a greater level of second language acquisition is below his opportunity cost of OC. Thus, the rational choice for this immigrant student is to leave school at the mandated age of 16 with good oral and minimum written second language skills. This outcome is due to both the disutility of learning (a component of OC) plus poor labour market prospects. Note that if this student had been given an incentive to stay in school to completion leaving age (18), a greater second language acquisition level (good written and oral) would have resulted.

Case B depicts the common case of immigrant student indifference between completing or not completing secondary school with its attendant greater second language facility. Again the 
student faces a constant costs curve $\mathrm{O}-\mathrm{C}$ but a much-improved marginal income reward from gaining second language facility above good oral and minimum written abilities. In fact, the point of inflexion for this marginal earnings curve occurs at age 18 to insure that this student, if economically rational, will complete secondary school.

\section{E. Conclusions:}

In sum, what do all these theoretical outcomes in these three spheres tell us about foreign-born second language acquisition? In short, unless citizenship and second language acquisition are simultaneously mandated by government, we argue that the economic characteristics of immigrants — skilled, unskilled or professional — will ultimately determine the optimum language acquired as dictated by the labour market. Thus, given capital market imperfections in the financing of second language acquisition, the most likely outcome is minimum oral skills with no written facility. This level of low language acquisition is also consistent with the most frequent optimum outcome in the remaining spheres of activities. In reality, though, a country sometimes only confers temporary immigrant status, which, after a waiting period, must be adjusted to state of citizenship, which in turn requires a partial mastering of the dominant language. Under this policy regime, the political sphere sets the minimum language acquisition. In this latter case, when the political model is dominant, we predict two sets of outcomes depending on the financing opportunities for second language acquisition. First, given family or government educational loans, highly skilled or professionally trained immigrants will voluntarily become citizens and enter into an occupation that matches their skill level. In the absence of financing, all but unskilled immigrants will return home or enter the unskilled occupational group in the destination country. 


\section{Bibliography}

Chapman, B., and R. Iredale. 1993. Immigrant qualifications: Recognition and relative wage outcomes. International Migration Review 27 (2): 359-87.

Chiswick, B., and P. Miller. n.d. Immigration, language and multiculturalism in Australia. Australian Economic Review, (forthcoming).

1995. The endogeneity between language and earnings: International analyses. Journal of Labour Economics 13 (2): 247-89.

Chiswick, B., and P. Miller. 1999. Language practice and the economic well-being of Immigrants. Policy Options (May): 45-50.

Dustman, C. 1994. Speaking fluency, writing fluency and earnings of migrants. Journal of Population Economics 7 (2): 226-36.

Gardiner, R. G. 1988. The socio-education model of second language learning. Language Learning 38 (1).

Gardner, R. C., and P. D. MacIntyre. 1992. A student's contributions to second-language learning. Part I: Cognitive variables. Language Teaching 25: 211-20.

Sweetman, A. 1999. Language skills hold back immigrant kids in math and science. Policy Options (May): 35-38.

VanPatten, B. 1999. What is second language acquisition and what is it doing in this department? ADFL Bulletin 30, no. 3 (Spring): 49-53.

Werner, C., H. Hinte, and D. DeVoretz. 2000. Immigrants and language lessons from Canada to Germany. IZADP 55, (forthcoming).

Zimmermann, K. F. 1999. Ethnic German migration since 1989: Results and perspectives, IZADP 50, August. 


\section{IZA Discussion Papers}

No. Author(s)

11

T. Bauer

R. T. Riphahn

12

R. Rotte

M. Vogler

13

R. Rotte

14

R. Hauser

G. G. Wagner

K. F. Zimmermann

15

R. T. Riphahn

16

T. Bauer

A. Million

R. Rotte

K. F. Zimmermann

17

R. T. Riphahn

B. Kreider

18

Z. Eckstein

K. I. Wolpin

19

C. Y. Co

I. N. Gang

M.-S. Yun

20

T. Bauer

P. T. Pereira

M. Vogler

K. F. Zimmermann

21 J. Ondrich

C. K. Spiess

Q. Yang

G. G. Wagner

22 A. Million

R. Rotte

K. F. Zimmermann

23 T. Bauer

K. F. Zimmermann
Title

Area

Date

Employment Effects of Payroll Taxes - An

$6 / 98$

Empirical Test for Germany

Determinants of International Migration: Empirical

Evidence for Migration from Developing Countries to Germany

Sorties from the Fortress: The Current System of Anti-Immigration Policies in Germany

Memorandum: Erfolgsbedingungen empirischer Wirtschaftsforschung und empirisch gestützter wirtschafts- und sozialpolitischer Beratung

Immigrant Participation in Social Assistance Programs

Immigrant Labor and Workplace Safety

Applications to the U.S. Disability System: A

3

$8 / 98$

Semiparametric Approach for Men and Women

Youth Employment and Academic Performance in High School

Returns to Returning: Who Went Abroad And What Does It Matter?

2

Portuguese Migrants in the German Labor Market: Performance and Self-Selection

2

The Liberalization of Maternity Leave Policy and $1 / 3$

$9 / 98$ the Return to Work after Childbirth in Germany

The Economics of Hospital Trips and Health Care

3

$9 / 98$ Reform

Learning Efficiency of Economics Students

7

$9 / 98$ 
24 K. F. Zimmermann

M. C. Burda

J. von Hagen

K. Konrad

F. Schneider

G. G. Wagner

K. Papps

R. Winkelmann

26

D. Enste

F. Schneider

27 E. Bratberg

$\varnothing$. A. Nilsen

U. Broll

K. P. Wong

29

D. J. Snower

30

J. Kluve

H. Lehmann

C. M. Schmidt

31

C. M. Schmidt

32

S.- Å. Dahl

$\varnothing$. A. Nilsen

K. Vaage

33 A. Lindbeck

D. J. Snower

34

P. A. Puhani

35

D. A. Jaeger

A. Huff Stevens

36

C. Lauer

H. S. Buscher

C. Müller

38 M. E. Ward

P. J. Sloane

39 A. Lindbeck

D. J. Snower

40

S. M. Golder

T. Straubhaar

Petersberger Erklärung: Anstöße für eine

Increasing Shadow Economies All Over the

World - Fiction or Reality?

Transitions from School to Work: Search Time

and Job Duration

Efficiency Wages and Futures Markets

$1 / 7$

$1 / 99$

Causes of Changing Earnings Inequality

Active Labor Market Policies in Poland:

Human Capital Enhancement, Stigmatization or Benefit Churning?

Persistence and the German Unemployment Problem: Empirical Evidence on German Labor

Market Flows

Work or Retirement? Exit Routes for Norwegian

Elderly

Price Dynamics and Production Lags

Labour Mobility - An Adjustment Mechanism in Euroland?

Is Job Stability in the United States Falling?

Reconciling Trends in the Current Population

Survey and Panel Study of Income Dynamics

The Effects of European Economic and Monetary Union on Wage Behaviour

Exchange Rate Volatility Effects on the German

Extensions

Job Satisfaction within the Scottish Academic

7

Profession

Multi-Task Learning and the Reorganization of

Work 


\begin{tabular}{|c|c|c|c|c|}
\hline 41 & $\begin{array}{l}\text { J. M. Orszag } \\
\text { D. J. Snower }\end{array}$ & Anatomy of Policy Complementarities & $3 / 7$ & $5 / 99$ \\
\hline 42 & D. S. Hamermesh & The Changing Distribution of Job Satisfaction & 7 & $5 / 99$ \\
\hline 43 & $\begin{array}{l}\text { C. Belzil } \\
\text { J. Hansen }\end{array}$ & $\begin{array}{l}\text { Household Characteristics, Ability and Education: } \\
\text { Evidence from a Dynamic Expected Utility Model }\end{array}$ & 7 & $5 / 99$ \\
\hline 44 & $\begin{array}{l}\text { D. N. F. Bell } \\
\text { R. A. Hart }\end{array}$ & $\begin{array}{l}\text { Overtime Working in an Unregulated Labour } \\
\text { Market }\end{array}$ & 1 & $6 / 99$ \\
\hline 45 & $\begin{array}{l}\text { R. A. Hart } \\
\text { J. R. Malley }\end{array}$ & On the Cyclicality and Stability of Real Earnings & 1 & $6 / 99$ \\
\hline 46 & $\begin{array}{l}\text { R. Rotte } \\
\text { M. Vogler }\end{array}$ & $\begin{array}{l}\text { The Effects of Development on Migration: } \\
\text { Theoretical Issues and New Empirical Evidence }\end{array}$ & 2 & $6 / 99$ \\
\hline 47 & $\begin{array}{l}\text { R. A. Hart } \\
\text { F. Ritchie }\end{array}$ & Tenure-based Wage Setting & $1 / 7$ & $7 / 99$ \\
\hline 48 & $\begin{array}{l}\text { T. Bauer } \\
\text { K. F. Zimmermann }\end{array}$ & $\begin{array}{l}\text { Overtime Work and Overtime Compensation in } \\
\text { Germany }\end{array}$ & 1 & $7 / 99$ \\
\hline 49 & H. P. Grüner & $\begin{array}{l}\text { Unemployment and Labor-Market Reform: A } \\
\text { Contract Theoretic Approach }\end{array}$ & $1 / 3$ & $7 / 99$ \\
\hline 50 & K. F. Zimmermann & $\begin{array}{l}\text { Ethnic German Migration After } 1989 \text { - Balance } \\
\text { and Perspectives }\end{array}$ & 1 & $8 / 99$ \\
\hline 51 & $\begin{array}{l}\text { A. Barrett } \\
\text { P. J. O'Connell }\end{array}$ & $\begin{array}{l}\text { Does Training Generally Work? } \\
\text { The Returns to In-Company Training }\end{array}$ & 7 & $8 / 99$ \\
\hline 52 & $\begin{array}{l}\text { J. Mayer } \\
\text { R. T. Riphahn }\end{array}$ & $\begin{array}{l}\text { Fertility Assimilation of Immigrants: Evidence } \\
\text { from Count Data Models }\end{array}$ & 3 & $8 / 99$ \\
\hline 53 & $\begin{array}{l}\text { J. Hartog } \\
\text { P. T. Pereira } \\
\text { J. A. C. Vieira }\end{array}$ & $\begin{array}{l}\text { Inter-industry Wage Dispersion in Portugal: high } \\
\text { but falling }\end{array}$ & 7 & $8 / 99$ \\
\hline 54 & M. Lofstrom & $\begin{array}{l}\text { Labor Market Assimilation and the } \\
\text { Self-Employment Decision of Immigrant } \\
\text { Entrepreneurs }\end{array}$ & 1 & $8 / 99$ \\
\hline 55 & L. Goerke & $\begin{array}{l}\text { Value-added Tax versus Social Security } \\
\text { Contributions }\end{array}$ & 3 & $8 / 99$ \\
\hline 56 & $\begin{array}{l}\text { A. Lindbeck } \\
\text { D. J. Snower }\end{array}$ & $\begin{array}{l}\text { Centralized Bargaining and Reorganized Work: } \\
\text { Are they compatible? }\end{array}$ & $1 / 5$ & 9/99 \\
\hline 57 & $\begin{array}{l}\text { I. N. Gang } \\
\text { K. F. Zimmermann }\end{array}$ & $\begin{array}{l}\text { Is Child like Parent? } \\
\text { Educational Attainment and Ethnic Origin }\end{array}$ & 1 & 9/99 \\
\hline 58 & $\begin{array}{l}\text { T. Bauer } \\
\text { K. F. Zimmermann }\end{array}$ & Occupational Mobility of Ethnic Migrants & 1 & 9/99 \\
\hline 59 & $\begin{array}{l}\text { D. J. DeVoretz } \\
\text { S. A. Laryea }\end{array}$ & $\begin{array}{l}\text { Canadian Immigration Experience: } \\
\text { Any Lessons for Europe? }\end{array}$ & $1 / 2 / 3$ & 9/99 \\
\hline 60 & $\begin{array}{l}\text { C. Belzil } \\
\text { J. Hansen }\end{array}$ & $\begin{array}{l}\text { Subjective Discount Rates, Intergenerational } \\
\text { Transfers and the Return to Schooling }\end{array}$ & 7 & $10 / 99$ \\
\hline
\end{tabular}


Ethnic German Immigration from Eastern Europe and the former Soviet Union to Germany: the Effects of Migrant Networks

69 M.-S. Yun
Generalized Selection Bias and the Decomposition $\quad 7$ of Wage Differentials

Immigrants and Unemployment in the European 1

Community

The Wedge

Are Austrian Returns to Education Falling Over $\quad 7$ Time?

The Endogenous Determination of Minimum Wage 3

Strategic Mismatches in Competing Teams

Adjustment Dynamics and the Natural Rate: An 1 Account of UK Unemployment

Selective Schools

Knowing What Works: The Case for Rigorous 6 $12 / 99$ Program Evaluation

Endogenous Schooling and the Distribution of the 7 Gender Wage Gap

Entrepreneurship from Scratch: Lessons on the 4 Entry Decision into Self-Employment from Transition Economies 
Aliyah to Israel: Immigration under Conditions of

The Rate of Return to Private Schooling

An Evaluation of Public-Sector-Sponsored Continuous Vocational Training Programs in East Germany

94 M. Eichler M. Lechner

An Evaluation of Public Employment Programmes in the East German State of Sachsen-Anhalt 
M. Rosholm

N. Smith

Estimation in a Duration Model for Evaluating

Different Skill Levels and Firing Costs in a

Ownership or Performance: What Determines Board of Directors' Turnover in Italy?

S. Bender

U. Hornsteiner

Job Tenure of Two Cohorts of Young German Men 1979 - 1990: An analysis of the (West-)German Employment Statistic Register Sample concerning multivariate failure times and unobserved heterogeneity

107 J. C. van Ours

Fast Track or Failure: A Study of the Completion

108 J. Boone

J. C. van Ours

Rates of Graduate Students in Economics

Modeling Financial Incentives to Get Unemployed $\quad 3 / 6 \quad 1 / 00$ Back to Work

109 G. J. van den Berg

Combining Micro and Macro Unemployment B. van der Klaauw Duration Data

110

D. DeVoretz

A Theory of Social Forces and Immigrant Second Language Acquisition 